\title{
Discrimination of the two subspecies of Microtus hartingi (Rodentia: Arvicolinae) by shape and linear features of the spermatozoon
}

\author{
Tanya A. Zorenko* \& Ugis E. Kagainis
}

\begin{abstract}
The Asian and European populations of Microtus hartingi have been isolated for a long time by the Straits of Dardanelle and the Bosporus, which could cause different degrees of divergence of morphological structures. The aim of this study was to compare the shape and linear features of spermatozoa of two subspecies of $M$. hartingi using different methods - geometric and linear morphometrics. The results obtained showed that geometric morphometrics more precisely demonstrates the change in the shape of the spermatozoon of two taxa. The shape of the spermatozoa head of $M$. $h$. hartingi is globular, with retracted basal part compared to the slimmer head with a stronger developed basal protrusion in $M$. h. lydius. The variability of the head shape is insignificant within each taxon, while considerable polymorphism is shown for the shape of acrosome. We have identified several types of acrosome shape, of which two types dominate in the opposite ratio in the two subspecies. Other types of acrosome shape are rare. The question of the diversity of the acrosome shape is discussed. We recommend the method of geometric morphometry of spermatozoa to consider variations of this cell structure in mammals at species and subspecies levels. Linear morphometry of spermatozoa may be less successful due to the methodological features of the preparing spermatozoa slides for subsequent analysis; therefore, the dimensional parameters of spermatozoa differ significantly, which complicates their use in taxonomy.
\end{abstract}

How to cite this article: Zorenko T.A., Kagainis U.E. 2021. Discrimination of the two subspecies of Microtus hartingi (Rodentia: Arvicolinae) by shape and linear features of the spermatozoon // Russian J. Theriol. Vol.20. No.2. P.143-157. doi: 10.15298/rusjtheriol.20.2.04

KEY WORDS: geometric morphometrics, linear measurements, spermatozoa, shape, acrosome, divergence, Microtus hartingi.+

Tanya A. Zorenko [tatjana.zorenko@lu.lv], Department of Zoology and Animal Ecology, Faculty of Biology, University of Latvia, 1 Jelgava Street, LV-1004, Riga, Latvia; Ugis Kagainis [ugis.kagainis@lu.lv], Department of Zoology and Animal Ecology, Faculty of Biology, University of Latvia, 1 Jelgava Street, LV-1004, Riga, Latvia; Institute of Biology, University of Latvia, 3 Miera Street, LV-2169, Salaspils, Latvia.

\section{Распознавание двух подвидов Microtus hartingi (Rodentia: Arvicolinae) по форме и линейным параметрам сперматозоидов}

\section{Т.А. Зоренко*, У.Э. Кагайнис}

РЕЗЮМЕ. Азиатские и европейские популяции Microtus hartingi длительное время изолированы проливами Босфор и Дарданеллы, что могло вызвать разную степень дивергенции морфологических структур. Целью данного исследования было сравнение строения и формы сперматозоидов двух подвидов $M$. hartingi с помощью различных методов - геометрической и линейной морфометрии. Полученные результаты показали, что метод геометрической морфометрии четко демонстрирует изменение формы сперматозоида двух таксонов. Головка сперматозоида $M$. h. hartingi имеет овальную форму с вытянутой базальной частью, тогда как у $M$. h. lydius головка сперматозоида сравнительно узкая и вытянутая с более развитым базальным выступом. В пределах каждого таксона изменчивость формы головки сперматозоидов незначительная, тогда как для акросомы показан существенный полиморфизм. Выделено несколько типов формы акросомы, из которых доминируют два типа, соотношение которых противоположно у двух таксонов. Другие типы ее формы редки. Обсуждается вопрос о разнообразии формы акросомы. Мы рекомендуем метод геометрической морфометрии спер-

\footnotetext{
* Corresponding author
} 
матозоидов для рассмотрения вариаций данной клеточной структуры у млекопитающих на видовом и подвидовом уровне. Линейная морфометрия сперматозоидов может быть менее успешной из-за методических особенностей приготовления препаратов сперматозоидов для последующего анализа, в результате чего размерные показатели сперматозоидов существенно различаются, что затрудняет их использование в таксономии.

КЛЮЧЕВЫЕ СЛОВА: геометрическая морфометрия, линейная морфометрия, сперматозоиды, форма, акросома, дивергенция, Microtus hartingi.

\section{Introduction}

The mammalian spermatozoa, particularly these of rodents, are extremely complex cells and differ greatly in shape and dimensions (Cummins \& Woodall, 1985; Breed, 2005; Sánchez et al., 2013; Zorenko \& Golenishchev, 2015). Mammalian spermatozoa are highly variable in shape and linear parameters which makes possible widely use these cells in taxonomic studies (Aksenova, 1978; Breed, 2004, 2005; Horst van der et al., 2011; Zorenko \& Golenishchev, 2015) and in phylogenetic studies (Pitnick et al., 2009; Moore et al., 2013). Although the number of studies on spermatozoa is not so large, the results do show that the specific shape and dimensions of spermatozoa can be used to distinguish different rodent species, especially these that are closely related (Aksenova, 1978; Horst van der et al., 1991; Jeong et al., 2006; Zorenko \& Golenishchev, 2015).

Studies of mammalian spermatozoa are actively carried out using the linear morphometrics method (Sánchez et al., 2013), in combination with light or electron microscopy (Horst van der et al., 2011; Medarde et al., 2013). The most commonly used parameters are the length and width of spermatozoon head, the ratio head length to width and the length of its tail. However, depending on the method used, different interpretation of spermatozoa norm and pathology can arise (Davis $\&$ Gravance, 1994). The use of these parameters of the spermatozoon head shows recognition of vole species (Aksenova, 1978; Zorenko \& Golenishchev, 2015). The ratio of head length to its width in four species of subgenus Microtus Schrank, 1798 (Cricetidae: Arvicolinae) representatives is more than 1.7 , whereas in species of the subgenus Sumeriomys Argyropulo, 1933 - less than 1.7. The relation of the sperm tail medium part length to head length in the first group is higher than 2.8 times, but in the second - lowers than 2.8 times. Hydrodynamic efficiency may be achieved by modifications of the ratio head length/head width, resulting in a more elongated spermatozoon head, and this may be influenced by sperm competition (Tourmente et al., 2011).

These methods permit to trace the spermatozoa structure but do not provide complete information about their shape. In contrary, geometric morphometrics are based on data analysis of geometric coordinates of the shape of morphological structures rather than using linear, areal, or volumetric variables (Procrustes superimposition). This analysis is disentangled from absolute position, size, scale, and orientation (Rohlf \& Slice, 1990; Bookstein, 1996). Thereby, the geometric morphometrics can identify more precisely, which spermatozoa morphological traits differ between species, for example, the protrusion or retraction of the base of the head, the degree of curvature of the hook etc. (Sánchez et al., 2013).

Many factors may significantly affect the morphology of mammal spermatozoa. Changes in the spermatozoa head morphology may take place, for instance, because of the action of chemical agents; however, the effect of toxicants still is not clarified. The degradation of spermatozoa occurs in heavy pollution conditions leading to an increase in the proportion of spermatozoa with defects (Wyrobek \& Bruce, 1975; Miska-Schramm et al., 2017). At the same time, in other studies such effect of chemicals was not found (Ieradi et al., 2003; Smirnov \& Davidova, 2018). Changes of spermatozoa morphology may also be a result of genetic alterations such as Y chromosome deletions (Krzanowska et al., 1995; Ward \& Burgoyne, 2006) and mutations (MendozaLujambio et al., 2002). Inbreeding is another important factor that can influence the spermatozoa quality and their morphometric parameters. The increase of the presence of spermatozoa abnormalities correlate with the decreasing of their heterozygosity. However, much data has been obtained that the breeding between genetically close relatives does not always affect the quality and quantity of sperm (Roldan et al., 1998; Michalczyk et al., 2010; Terrell et al., 2016).

In recent years, an interesting hypothesis was put forward about a likely correlation between the number of spermatozoa and the level of their competition. The risk of competition affects the amount of spermatozoa per ejaculate. More often, the amount of sperm increases in the presence of rival males (delBarco-Trillo \& Ferkin, 2004). However, it is also possible to reduce the amount of spermatozoa per ejaculate (Ramm \& Stockley, 2007). The quality of the spermatozoa (absence of abnormalities in their shape and size) may have a certain effect on this reaction by changing the amount of sperm and the spermatozoa competition. Sperm competition can affect the design and size of spermatozoa, in particular, it lead to elongation of the head, which increases spermatozoa motility (Tourmante et al., 2011).

The question "Which shape of spermatozoa is the initial in the evolution of rodent spermatozoa: a) simple form with a bold cone-shaped head or b) complex form with a hook-type head?" remains unresolved. According to the hypothesis by Roldan et al. (1992), the spermatozoa initially had a simple design which under the impact of various factors, could become complicated 
during evolution. However, a comparative analysis of the spermatozoa shape in many species shows that a more complex form with the characteristic hook is the most common among different families of rodents. Perhaps the hook-shaped structure of spermatozoa is the ancestral structure. Aksenova (1978), who distinguished three forms of head and acrosome shape of spermatozoa in the tribe Microtini Simpson, 1945, expressed this hypothesis. In many species related to different genera such as Microtus s. str., Alexandromys Ognev, 1914 (e.g., A. fortis (Büchner, 1881), Blanfordimys Argyropulo, 1933, Lasiopodomys brandtii (Radde, 1861) and L. gregalis (Pallas, 1779) (Abramson \& Lissovsky, 2012) the spermatozoa head is hook-shaped (form 1). In other species, the head is oval, and acrosome represents a coneshaped hillock, which lies deep under the cell body (form 2 ) or covers a cell body upwards (form 3 ). The second form is noted in some species of the genus Alexandromys (A. middendorffii (Poljakov, 1881), A. maximowiczii (Schrenk, 1858) and A. sachalinensis (Vasin, 1955) whereas the third is found only in the representative of the subgenus Sumeriomys (Aksenova, 1978; Zorenko \& Golenishchev, 2015). Breed (2005) after analysing species from several families of rodents concluded that certain species and hook-shaped spermatozoa acquired the simple form of spermatozoa later is likely the ancestral structure within the Muroidea.

The "guentheri" group (Ellerman, 1941) previously included one polytypic species — the Gunter's vole M. guentheri Danford et Alston, 1880 with a karyotype of $2 n=54$ (Golenishchev et al., 2002), which occupied a wide range from Israel, Lebanon, Syria to the Balkans and Africa (Gromov \& Polyakov, 1977; Musser $\&$ Carleton, 2005). Molecular studies with the use of mitochondrial cyt $b$ marker showed that $M$. guentheri is present in eastern Anatolia, but in western Anatolia and Europe (Thrace) M. hartingi Barret-Hamilton, 1903 is distributed (Kryštufek et al., 2009). Both species are isolated from each other by a mountain range (Anatolian Diagonal) (Yiğit \& Çolak, 2002). Microtus hartingi is distributed in central and northwestern Anatolia and the Balkans. However, populations from Thrace and western Anatolia have long been isolated. The Straits of Dardanelle and the Bosporus formed in the late Pliocene 2 million years ago (Çağatay et al., 2000; Yaltırak et al., 2000), and some authors believe that the strains blocked the flow of genes between Asia and Europe populations and promoted species formation (Yigit \& Çolak, 2002; Yiğit et al., 2012).

The aim of this study was to compare spermatozoa shape and dimensions of two subspecies of $M$. hartingi, using two different methods: the geometric morphometrics and linear morphometrics.

\section{Materials and methods}

The rodent material and ethical standards

The founders of $M$. hartingi laboratory colonies were captured in two localities from the distribution range of this species: $M$. h. hartingi (10 individuals from Eastern Rodope Mountains, Bulgaria, N 41.68 ${ }^{\circ}$, E 26.2 ${ }^{\circ}$ ), and M. h. lydius ( 8 individuals from the vicinity of Kırşehir, Turkey, N $39.13^{\circ}, \mathrm{E} 34.15^{\circ}$ ). This investigation was carried out using the collected animals in the Laboratory of Ethology (University of Latvia). Reproductive and sexually active males of $M$. h. hartingi (7 individuals), and $M$. h. lydius ( 8 individuals) aged 4-6 months for sperm analysis were used. Males were sacrificed by cervical dislocation. All applicable international, national, and/ or institutional guidelines for the care and use of animals for investigations were respected (Guillén, 2017). All the procedures performed in this study were in accordance of the European directive no. 2010/63/EU and of Latvian regulations (Latvian Council of Science, 2018) resulting from this directive.

After the animal dissection, cauda epididymidis were cut and placed in $1 \mathrm{ml}$ of saline solution for 2 hours at $37^{\circ} \mathrm{C}$ to allow sperm cells to swim out. Spermatozoa were smeared onto slides, fixed with formaldehyde (4\%) in a phosphate buffer ( $\mathrm{pH} 7.4$ ) in $20 \mu \mathrm{l}$ for 20 minutes. In addition, spermatozoa samples of four males (No.512, No.533 for $M$. $h$. hartingi and No.714, No.803 for $M$. $h$. lydius subspecies) were additionally stained with the methylene blue for 10 minutes as previously described (Zorenko \& Golenishchev, 2015) and examined using bright field microscopy. All samples were evaluated at $400^{\times}$magnification for subsequent digitalization using an Olympus BX41 microscope. Only spermatozoa cells with the head projected in total profile were accepted for further research and were assigned for the following two stages: 1) analysis of the general morphology of spermatozoa and 2) geometric morphometrics and shape analysis.

\section{Analysis of the linear morphology}

The following linear measurements were taken: the greatest head length and width, head length without acrosome, acrosome height and width. Besides, we calculated the index was as the ratio of head length to its width. For every subspecies of the Harting' vole, it was received 125 spermatozoa of $M$. h. hartingi and 160 spermatozoa of $M$. h. lydius. We obtained the linear and geometric dimensions for the same spermatozoa. We calculated the arithmetic mean and its standard error for every measurement, and compared arithmetic means by Student's t-test.

\section{Analysis of the general morphology}

Microscope slides containing the spermatozoa were observed in twelve to fourteen randomly selected fields of view $(100 \mu \mathrm{m} \times 100 \mu \mathrm{m}$ each $)$ set for each individual. Spermatozoa tail defects (cells with tail loss and tails with gins), as well as the variability of the spermatozoa head morphology (Fig. 1) were calculated as the percent of occurrence among the total number of spermatozoids observed. In total, more than 800 spermatozoa cells for both vole taxa were counted among 17 slides and characterised by means of qualitative morphological traits only. 


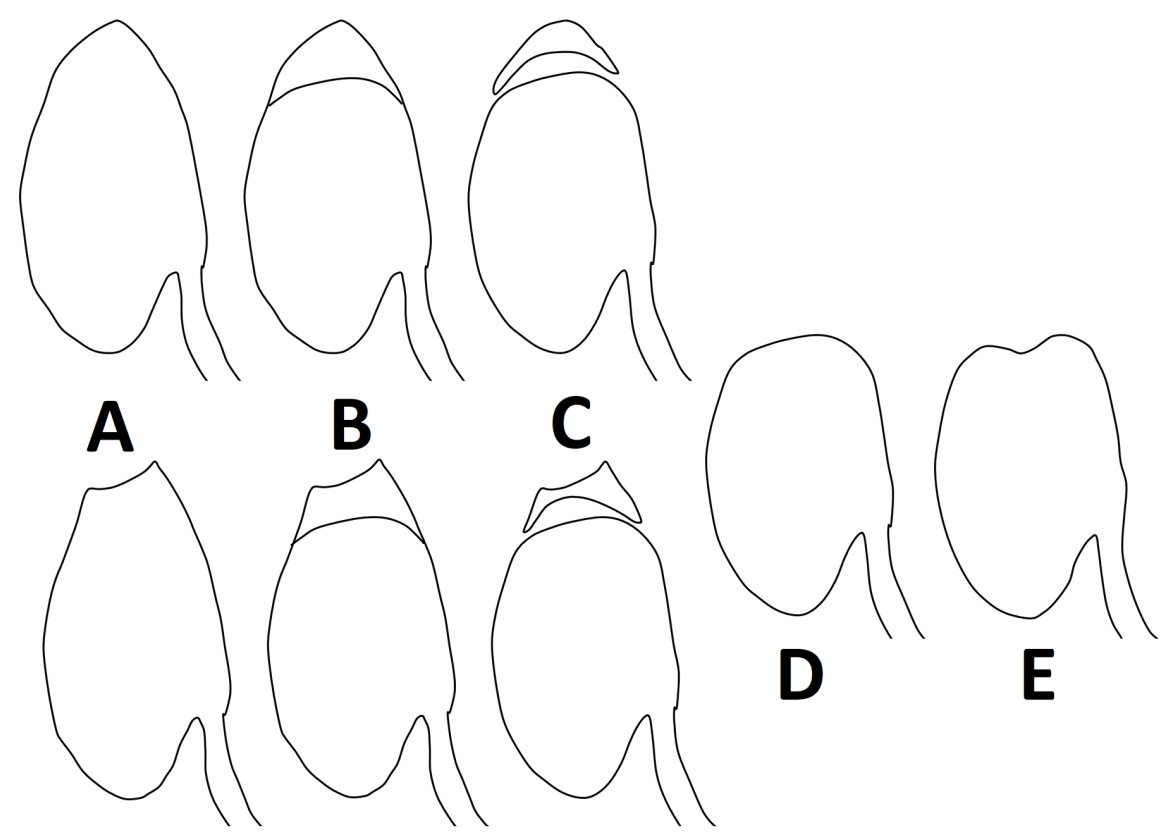

Fig. 1. Variation in Microtus hartingi spermatozoid head morphology according to morphological differences in singe-tip and double-tip shaped acrosome; "full" (A) — acrosome visible, yet fully fused with the sperm head, "thin" (B) — acrosome visible and separated from the sperm head by the thin but discernible line, "empty" (C) - highly transparent (empty-like) acrosome separated apart from the sperm head totally, "glob" (D) - acrosome not discernible from the sperm head, apex of the head round forming the profile of head globular in shape; "push" (E) - acrosome absent, the apex of the head with depression as it was partially pushed inwards.

Shape analysis, data processing and statistical analysis

The same microscopic slides observed in the analysis of general morphology were used further. Spermatozoa with strong deformities or damage (e.g., tail loss, tail with gins) or overlapped spermatozoa were not photographed. Photos were made at $1000^{\times}$magnification across all samples using an Olympus DP12 digital camera. For each male, if possible, on average of 20 randomly chosen laterally positioned spermatozoa with dorsal side facing left were photographed, and images were digitally edited using Adobe ${ }^{\circledR}$ Photoshop. Regions with spermatozoa heads were digitally cropped out from the images of each primal photo. Cropped files were made as $150 \times$ 150-pixel squares, resized ten times larger and saved as TIFFs of 1500 square-pixels.

First, all images were sorted into separate groups according to the general morphology of the acrosome of the spermatozoa head. Names of the five morphological sub-groups: "full", "thin", "empty", "glob" and "push" (see Fig. 1) and two variations, single-tip and double-tip acrosome (apex of the head), were accordingly set for the images using tpsUtil32. They were derived by following visual differences observed during the light microscopy (Fig. 1).

Next, 18 landmarks from the spermatozoa head, 6 landmarks from the acrosome with a single tip and 13 from the acrosome with a double tip were digitized by tpsDig32 (Tabs 1,2). As far as two types of acro- some were registered (i.e., single-tip and double-tip), semilandmarks were assigned only to the ventral side of the acrosome. By doing this, we maintained the possibility for standardised shape comparison among all sperm heads meanwhile not affecting the possibility for shape interpretation of the triangularly formed single-tip acrosome. General landmarks were chosen as discrete anatomical loci that are biologically meaningful and semi-landmarks were assigned to the points arrayed along the curves (Rohlf \& Slice, 1990; Bookstein, 1996). Multiple segments of curves were drawn, combined, and digitized also by using tpsDig32 (Rohlf, 2016). The two subspecies $M$. h. hartingi and $M$. $h$. lydius were set as two different data groups including two different datasets of landmarks from the head and the acrosome. MorphoJ 1.06d (Klingenberg, 2011) performed generalized Procrustes Analysis (GPA), Principal Component Analysis (PCA), Canonical Variance Analysis (CVA) and Discriminant Function Analysis (DFA).

For the analysis of the general morphology among random fields of view, data were tested via several statistic tests using R (ver. 3.0.1) software environment for statistical computing and graphics as follows. For the analysis of normal distribution, the KolmogorovSmirnov's test was executed and the standard deviation was calculated for all datasets. Further, the hypothesis of homogeneity of variances was tested among both datasets of the two subspecies and datasets of spermatozoa unstained vs. stained with methylene blue (Levene's 
Table 1. Characteristics of the sample sizes by means of the number of $M$. hartingi hartingi and $M$. h. lydius males and the total number of spermatozoa per each sub-dataset of individuals used in the statistical analysis, among various morphologically different groups.

\begin{tabular}{|l|l|c|c|}
\hline \multicolumn{2}{|c|}{} & \multicolumn{2}{c|}{ Sample size of individuals } \\
\hline Sub-datasets (sperm shape types) & \multicolumn{1}{|c|}{ Subspecies } & As number of males & As total number of spermatozoa \\
\hline \multirow{2}{*}{ Single-tip, «full+glob» } & M. h. hartingi & 7 & 50 \\
& M. h. lydius & 8 & 96 \\
\hline \multirow{2}{*}{ Single-tip, «thin» } & M. h. hartingi & 6 & 54 \\
& M. h. lydius & 8 & 96 \\
\hline \multirow{2}{*}{ Single-tip, «empty» } & M. h. hartingi & 4 & 44 \\
& M. h. lydius & 6 & 12 \\
\hline \multirow{2}{*}{ Single-tip, «push» } & M. h. hartingi & 3 & 4 \\
& M. h. lydius & 5 & 13 \\
\hline \multirow{2}{*}{ Double-tip head, «thin+empty» } & M. h. hartingi & 5 & 45 \\
& M. h. lydius & 5 & 10 \\
\hline
\end{tabular}

Table 2. Landmarks (I) and semilandmarks used to assess spermatozoon head morphology. See Fig. 2.

\begin{tabular}{|c|c|c|}
\hline $\begin{array}{l}\text { Land- } \\
\text { mark } \\
\text { number }\end{array}$ & Description & Landmark type \\
\hline 1 & Insertion point of Flagellum, on the ventral side of the posterior ring & $\mathrm{I}$ \\
\hline 2 & Insertion point of Flagellum, on the dorsal side of the posterior ring & I \\
\hline 3 & Point of maximum length in head main axis (basal position) & $\mathrm{I}$ \\
\hline 4 & Maximum head width on the dorsal side of sperm & I \\
\hline 5 & Point of maximum length in head main axis (apical position) & $\mathrm{I}$ \\
\hline 6 & Maximum head width on the ventral side of sperm & I \\
\hline 7 & Point of insertion of the basal end of acrosome in the ventral side of the head & I \\
\hline 8 & Tip of the primary peak of acrosome (apical position) & $\mathrm{I}$ \\
\hline 9 & Tip of the secondary peak of acrosome (apical position) & I \\
\hline 10 & Point of insertion of the basal end of acrosome in the dorsal side of the head & $\mathrm{I}$ \\
\hline 11 & Point at half of the distance between landmarks 2 and 3 & semilandmark \\
\hline 12 & Point at half of the distance between landmarks 2 and 11 & semilandmark \\
\hline 13 & Point at half of the distance between landmarks 3 and 11 & semilandmark \\
\hline 14 & Point at half of the distance between landmarks 3 and 4 & semilandmark \\
\hline 15 & Point at half of the distance between landmarks 3 and 14 & semilandmark \\
\hline 16 & Point at half of the distance between landmarks 4 and 14 & semilandmark \\
\hline 17 & Point at half of the distance between landmarks 4 and 5 & semilandmark \\
\hline 18 & Point at half of the distance between landmarks 4 and 17 & semilandmark \\
\hline 19 & Point at half of the distance between landmarks 5 and 17 & semilandmark \\
\hline 20 & Point at half of the distance between landmarks 5 and 6 & semilandmark \\
\hline 21 & Point at half of the distance between landmarks 5 and 20 & semilandmark \\
\hline 22 & Point at half of the distance between landmarks 6 and 20 & semilandmar \\
\hline 23 & Point at half of the distance between landmarks 7 and 8 & semilandmark \\
\hline 24 & Point at half of the distance between landmarks 7 and 23 & semilandmark \\
\hline 25 & Point at half of the distance between landmarks 8 and 23 & semilandmark \\
\hline 26 & Point at half of the distance between landmarks 8 and 9 & semilandmark \\
\hline 27 & Point at half of the distance between landmarks 8 and 26 & semilandmark \\
\hline 28 & Point at half of the distance between landmarks 9 and 26 & semilandmark \\
\hline 29 & Point at half of the distance between landmarks 9 and 10 & semilandmark \\
\hline 30 & Point at half of the distance between landmarks 9 and 29 & semilandmark \\
\hline 31 & Point at half of the distance between landmarks 10 and 29 & semilandmark \\
\hline
\end{tabular}



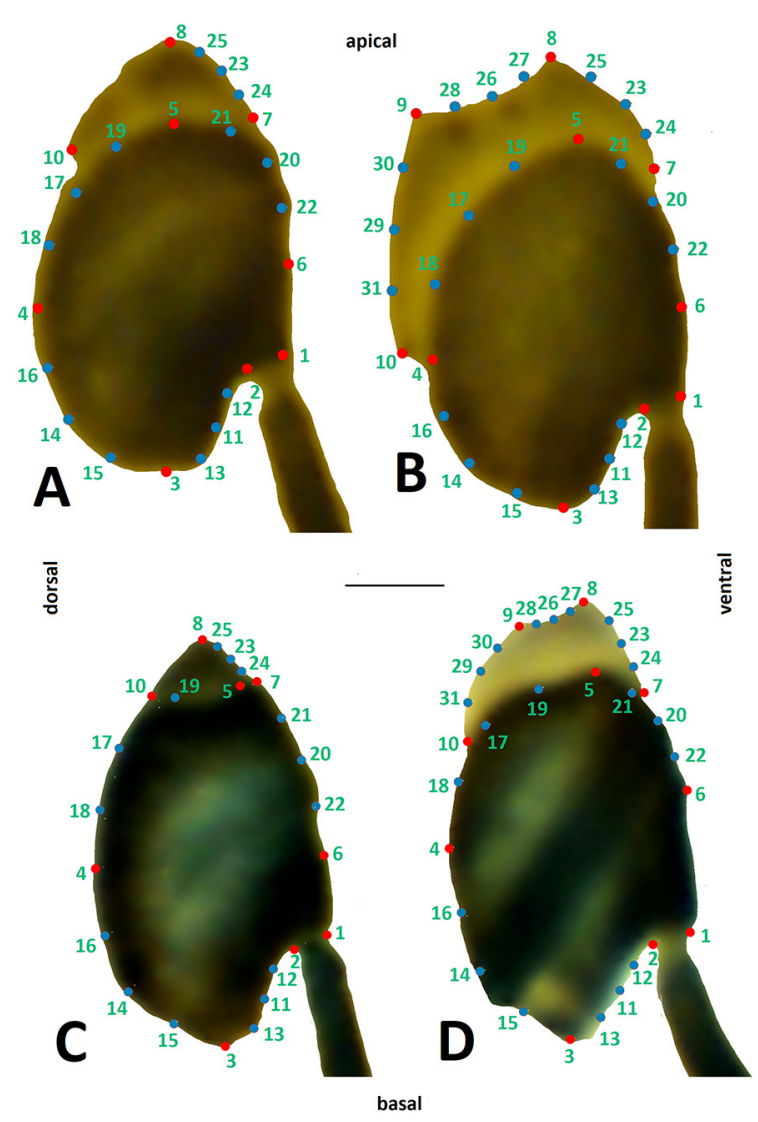

Fig. 2. Distribution of landmarks (red circles) and semilandmarks (blue circles) on single-tip (left) and doubletip (right) sperm head of Microtus hartingi hartingi (A, B) M. h. lydius (C, D) (scale bar: $2 \mu \mathrm{m}$ ) with two acrosome types: single-tip (A, C) and double-tip (B, D) peak of the acrosome.

test, $p>0.05)$. Furthermore, the statistical significance of the correlations between two samples was checked with the Student's t distribution test and Fisher's test (R Development Core Team, 2019).

Since sub-datasets of single-tip "glob" and doubletip "empty" were represented by too few spermatozoa investigated, they were combined to morphologically most similar sub-datasets of single-tip "full" and doubletip "thin" respectively, and named as follows: single-tip "full+glob" and double-tip "thin+empty" (Tab. 1).

\section{Results}

The size of the spermatozoon head of two taxa of $M$. hartingi is statically different in five parameters (Tab. $3)$. Spermatozoa length of $M$. $h$. lydius is noticeably longer both with and without acrosome than in $M$. $h$. hartingi. The spermatozoa head width in two subspecies differs little but its variability varies over a wide range, about two $\mu \kappa$. On the contrary, the acrosome height is higher in the $M$. h. hartingi (Tab. 3). The ratio of head length to its width (L/D) in individuals of this vole's species and average values of two subspecies significantly differs (Tab. 3) that indicates an elongation of the head in $M$. h. lydius. The spermatozoon neck width is simple in both taxa $(0.75 \pm 0.01)$.

In total, among the 97 fields of view for $M$. h. hartingi and 126 fields of view for $M$. h. lydius respectively, 354 and 478 spermatozoa for each taxon were investigated during the microscopy. Data on the general morphology analysis of spermatozoa are summarized in the Table 4. It was impossible to separate visually between "empty" and "thin" spermatozoa during the microscopy, due to lower resolution in $400 \times$ magnifications, which is why data on the "empty" is combined with data on the "thin" in the Table 4. Thus, the cells of "empty" type were all counted in the same group as the cells of the "thin" type. Data of most of the datasets confirmed the hypothesis for normal distribution with the exception of the dataset "glob" of the $M$. h. lydius males.

According to the results indicated by Student's t distribution test and Fisher's test, samples representing data on the general morphology analysis in most cases did not significantly differ between the unstained spermatozoa versus the methylene blue stained cells). Tail loss was the only characteristic for which both tests proved statistical significance $\left(\mathrm{T}=-2.98 ; p=0.0045\right.$ and $\chi^{2}=103.82 ; p=$ $0.0225)$ of the difference between the samples. This defect was registered about four times more frequent for $M$. h. lydius spermatozoa stained with methylene blue compared to the unstained samples (Tab. 5).

Procrustes ANOVA analysis of size (as centroid size) and shape variation confirmed statistically significant difference among certain sub-datasets between the two subspecies $M$. h. lydius and $M$. $h$. hartingi. Between the two subspecies a statistically most significant difference was registered in centroid size of the acrosome

Table 3. The linear dimensions of spermatozoa. Abbreviations: L — head length; D — head width; L/a — head length without acrosome; L / D — head length / head width ratio; H — acrosome height

\begin{tabular}{|l|c|c|c|c|c|}
\hline \multicolumn{1}{|c|}{ Taxon } & $\mathbf{L}, \mu \mathrm{k}$ & $\mathbf{D}, \mu \mathrm{k}$ & $\mathbf{L} / \mathbf{a}, \mu \mathrm{k}$ & $\mathbf{L} / \mathbf{D}$ & $\mathbf{H}, \mu \mathrm{k}$ \\
\hline \multirow{2}{*}{ M. h. hartingi } & $\mathbf{7 . 6 0} \pm 0.07$ & $\mathbf{4 . 9 8} \pm 0.04$ & $\mathbf{7 . 1} \pm 0.06$ & $\mathbf{1 . 5 3} \pm 0.01$ & $\mathbf{1 . 6} \pm 0.06$ \\
& $(6.0-8.9)$ & $(3.9-5.91)$ & $(5.7-8.9)$ & $(1.1-1.78)$ & $(0.5-3.7)$ \\
\hline \multirow{2}{*}{ M. h. lydius } & $\mathbf{8 . 1 7} \pm 0.05$ & $\mathbf{5 . 1 0} \pm 0.04$ & $\mathbf{7 . 9} \pm 0.07$ & $\mathbf{1 . 6 1} \pm 0.01$ & $\mathbf{1 . 3} \pm 0.04$ \\
& $(6.3-9.67)$ & $(3.9-6.14)$ & $(5.9-10.0)$ & $(1.5-1.7)$ & $(0.5-2.7)$ \\
\hline \multirow{2}{*}{$p$-value } & $\mathrm{df}=282, t=6.33$, & $\mathrm{df}=282, t=2.14$, & $\mathrm{df}=282, t=8.8$, & $\mathrm{df}=282, t=8.8$, & $\mathrm{df}=215, t=4.28$, \\
& $\boldsymbol{p}<\mathbf{0 . 0 0 1}$ & $\boldsymbol{p}<\mathbf{0 . 0 5}$ & $\boldsymbol{p}<\mathbf{0 . 0 0 1}$ & $\boldsymbol{p}<\mathbf{0 . 0 0 1}$ & $\boldsymbol{p}<\mathbf{0 . 0 0 1}$ \\
\hline
\end{tabular}


Table 4. Accounting results for tail defects, double-tip acrosomes, and shape varieties between both subspecies (numbers divided with slash refers to $M$. hartingi hartingi (hart, on the left) and $M$. h. lydius (lydi, on the right, respectively)). N number of counted cells; Prop \% - the population number difference in percent of each group of type shown as the division number between both subspecies; $\mathrm{T}(\mathrm{t}$-test $)$ - T value of the Student's t distribution test; $\mathrm{p}(\mathrm{t}$-test $)$ - $\mathrm{p}$ value of the Student's

t-test; $X^{2}$ (F-test) - X squared value of the Fisher's test; (F-test) — p value of the Fisher's test. Tail defects: tail loss (loss)

and tail gins (gins), and shape types: "full", "thin", "empty", "glob" and "push" (explanations for the abbreviated names of shape types see in Fig. 1); Statistically significant $\mathrm{p}$-values $(\mathrm{p}<0.05)$ are in bold; Prop \% calculated from the data of Geometric Morphometrics and shape analysis is abbreviated with the asterisk *; absent values abbreviated with N/A.

\begin{tabular}{|l|c|c|c|c|c|c|c|}
\hline & \multicolumn{2}{|c|}{ Tail defects } & \multicolumn{2}{c|}{ Acrosome } & \multicolumn{3}{c|}{ Head shape types } \\
\hline & loss & gins & double-tip & «full» & $\begin{array}{c}\text { «empty» } \\
\text { «thin» }\end{array}$ & «glob» & «push» \\
\hline $\mathrm{N}$ & $41 / 53$ & $64 / 38$ & $52 / 9$ & $121 / 280$ & $218 / 171$ & $8 / 2$ & $7 / 25$ \\
Prop \% & $39 / 58$ & $61 / 42$ & $85 / 15$ & $34 / 58$ & $62 / 36$ & $2 /<1$ & $2 / 5$ \\
\hline $\mathrm{T}$ (t-test) & -0.23 & 1.32 & 1.68 & -2.10 & 0.66 & 1.33 & -1.14 \\
$\mathrm{p}(\mathrm{t}$-test) & 0.82 & 0.22 & 0.14 & 0.06 & 0.52 & 0.22 & 0.28 \\
\hline $\mathrm{X}^{2}$ (F-test) & $\mathrm{N} / \mathrm{A}$ & 9.8 & $\mathrm{~N} / \mathrm{A}$ & 17.99 & 56.02 & $\mathrm{~N} / \mathrm{A}$ & $\mathrm{N} / \mathrm{A}$ \\
$\mathrm{p}($ F-test) & $\mathrm{N} / \mathrm{A}$ & 0.2 & $\mathrm{~N} / \mathrm{A}$ & $\mathbf{0 . 0 1}$ & $\mathbf{9 . 3 * 1 0 - 1 0}$ & $\mathrm{N} / \mathrm{A}$ & $\mathrm{N} / \mathrm{A}$ \\
\hline Prop \%* & $\mathrm{N} / \mathrm{A}$ & $\mathrm{N} / \mathrm{A}$ & $82 / 18$ & $33 / 44$ & $35 / 44$ & $1 / 1$ & $3 / 6$ \\
\hline
\end{tabular}

Table 5. T values of the Student's t. distribution test (t-test) and X squared values of the Fisher's test (F-test) used for calculating differences between methylene blue stained and unstained samples of Microtus hartingi hartingi and M. h. lydius

voles' occurrence data on tail defects, double-tip acrosomes and spermatozoa head shape varieties. $\mathrm{p}(\mathrm{t}$-test $)$ - $\mathrm{p}$ value of the Student's t-test; $p$ (F-test) — p value of the Fisher's test. Tail defects: tail loss (loss) and tail gins (gins), and shape types: "full", "thin", "empty", "glob" and "push" (explanations for the abbreviated names of shape types see in Fig. 1); Statistically significant $\mathrm{p}$-values $(\mathrm{p}<0.05)$ are in bold; absent values abbreviated with N/A.

\begin{tabular}{|c|c|c|c|c|c|c|c|}
\hline & \multicolumn{2}{|c|}{ Tail defects } & \multicolumn{2}{|c|}{ Acrosome } & \multicolumn{3}{|c|}{ Head shape types } \\
\hline & loss & gins & double-tip & «full» & $\begin{array}{c}\text { «empty» } \\
\text { «thin» }\end{array}$ & «glob» & «push» \\
\hline \multicolumn{8}{|c|}{ M. h. hartingi } \\
\hline $\mathrm{T}(\mathrm{t}$-test $)$ & -3.2 & -2.22 & 1.52 & 1.53 & -0.99 & -0.06 & -1.98 \\
\hline $\mathrm{p}(\mathrm{t}$-test $)$ & $2.1 * 10^{-3}$ & 0.03 & 0.13 & 0.13 & 0.33 & 0.95 & 0.06 \\
\hline $\mathrm{X}^{2}(\mathrm{~F}$-test $)$ & 35.95 & 47.68 & 16.59 & 88.03 & 55.6 & 40.03 & N/A \\
\hline $\mathrm{p}(\mathrm{F}$-test $)$ & 0.65 & 0.75 & 0.99 & 0.18 & 0.82 & $4.3 * 10^{-8}$ & N/A \\
\hline \multicolumn{8}{|c|}{ M.h. lydius } \\
\hline $\mathrm{T}(\mathrm{t}$-test $)$ & -2.98 & -1.11 & 3.47 & 3.47 & -2.12 & 1.43 & -2.5 \\
\hline $\mathrm{p}(\mathrm{t}$-test $)$ & $4.5 * 10^{-3}$ & 0.27 & $8.7 * 10^{-4}$ & $8.7 * 10^{-4}$ & 0.04 & 0.12 & 0.02 \\
\hline $\mathrm{X}^{2}(\mathrm{~F}$-test $)$ & 103.82 & 43.89 & 0 & 69.44 & 37.32 & N/A & 0.81 \\
\hline $\mathrm{p}(\mathrm{F}$-test $)$ & 0.02 & 0.72 & 0.99 & 0.99 & 0.99 & $\mathrm{~N} / \mathrm{A}$ & 0.99 \\
\hline
\end{tabular}

single-tip "thin" sub-datasets and single-tip "full+glob" and "empty" sub-datasets for head morphology (Tab. 5). For the shape variation, the most significant difference between the subspecies was in single-tip "full+glob", "thin" and "empty" sub-datasets for head morphology and in single-tip "thin" and in double-tip "thin+empty" sub-datasets for acrosome morphology (Tab. 5, Fig. 1). However, among the mentioned, the p-value of the Pillai trace index showed a statistically non-significant differences in single-tip "push" datasets for head morphology and in double-tip "thin+empty" sub-datasets for acrosome morphology. No statistically significant difference between both $M$. hartingi subspecies for neither centroid size nor shape was registered in single-tip "empty" and "push" sub-datasets for acrosome and head morphology respectively (Tab. 5).
In PCA analysis, the most significantly pronounced morphological variation by the first five PCs were for single-tip "thin" sub-datasets of the acrosome morphology (Tab. 6). However, relatively lower variance was explained by PC1 and PC 2 in the singletip "full+glob" and "empty" sub-datasets of the head morphology, compared to the variance of first five PCs (Tab. 6). For other sub-datasets, the morphological variability could be explained by statistically not significant data variance between the two subspecies.

In the positive directional shape, changes in PCA were referenced to the contraction of the acrosome peak affecting $\mathrm{PC} 1$, and the stretch of acrosome in the apical position affecting PC2 for single-tip "thin" datasets (Fig. 3C). In cases of sub-datasets for head morphology of single-tip "full+glob" spermatozoa, PC1 

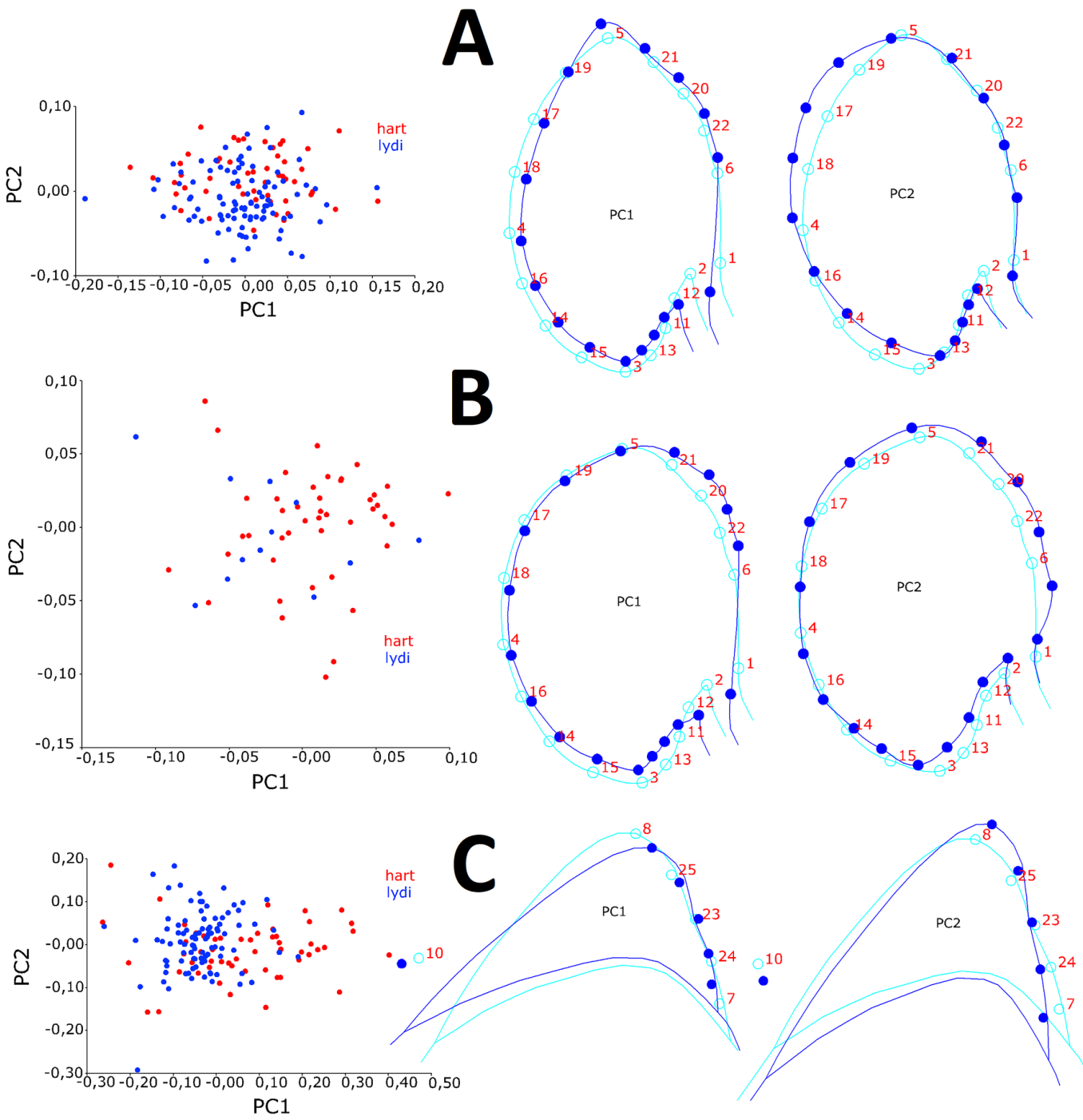

Fig. 3. Scatter plots of PCA (on left) and positive directional shape changes of $\mathrm{PC} 1$ and $\mathrm{PC} 2$ coloured in dark blue compared to consensus shape coloured in light blue (on right) of the head (A, B) and acrosome (C) morphology among two vole subspecies (hart: Microtus hartingi hartingi marked red, lydi: M. h. lydius marked blue; consensus and deformation landmarks symbolised by empty and filled dots respectively and numbered in red; scale factor: 0.13 ).

Table 6. Procrustes ANOVA results (F: Goodal's F, CS: Centroid Size, Bolded: statistically significant difference, Pill: Pillai trace) for two vole subspecies Microtus hartingi hartingi and M. h. lydius. Statistically significant p-values $(p<0.05)$ are in bold; absent values abbreviated with N/A.

\begin{tabular}{|c|c|c|c|c|c|c|}
\hline Individuals & Dataset & Data type & $\mathrm{F}$ & p-value & Pill & $\mathrm{p}$-value \\
\hline \multirow[t]{2}{*}{ Single-tip «full+glob } & Head & $\mathrm{CS}$ & 82.26 & $<0.0001$ & N/A & $\mathrm{N} / \mathrm{A}$ \\
\hline & & Shape & 8.58 & $<0.0001$ & 0.68 & $<0.0001$ \\
\hline \multirow[t]{4}{*}{ Single-tip «thin» } & Acrosome & $\mathrm{CS}$ & 18.47 & $<0.0001$ & N/A & $\mathrm{N} / \mathrm{A}$ \\
\hline & & Shape & 20.67 & $<0.0001$ & 0.27 & $<0.0001$ \\
\hline & & $\mathrm{CS}$ & 2.96 & 0.0876 & N/A & $\mathrm{N} / \mathrm{A}$ \\
\hline & Head & Shape & 16.76 & $<0.0001$ & 0.66 & $<0.0001$ \\
\hline \multirow{4}{*}{ Single-tip «empty» } & & $\mathrm{CS}$ & 0.14 & 0.7099 & N/A & $\mathrm{N} / \mathrm{A}$ \\
\hline & Acrosome & Shape & 0.58 & 0.7934 & 0.13 & 0.5264 \\
\hline & Head & $\mathrm{CS}$ & 4.3 & 0.043 & N/A & N/A \\
\hline & Head & Shape & 6.06 & $<0.0001$ & 0.9 & $<0.0001$ \\
\hline \multirow{2}{*}{ Single-tip «push» } & \multirow{2}{*}{ Head } & $\mathrm{CS}$ & 17.77 & 0.0007 & N/A & $\mathrm{N} / \mathrm{A}$ \\
\hline & & Shape & -69.38 & $\mathrm{NaN}$ & 0 & 1 \\
\hline \multirow{2}{*}{$\begin{array}{l}\text { Double-tip } \\
\text { «thin+empty» }\end{array}$} & \multirow{2}{*}{ Acrosome } & $\mathrm{CS}$ & 1 & 0.3227 & N/A & $\mathrm{N} / \mathrm{A}$ \\
\hline & & Shape & 4.6 & $<0.0001$ & 0.51 & 0.1358 \\
\hline
\end{tabular}


was affected by more pinned tip of the acrosome and narrower, slenderer head (Fig. 3A). Sub-datasets of the head morphology of single-tip "empty" spermatozoa were characterized by more globular shape (especially on the dorsal side of the apical position, formed by landmarks 20, 21 and 22, see Tab. 2 for the reference) affecting both PC1 and PC2. Similarly, the shape was characterized also by the contraction of the basal part ventrally (by landmarks 2, 3, 11, 12, 13) as well as less protruding ventral side near the insertion point of Flagellum (landmarks 1 and 6) affecting PC2 and vice versa affecting PC1.

In CVA, significant differences were statistically proved according to permutation $\mathrm{p}$ values calculated for both Mahalanobis and Procrustes distances (Tab. 7). Samples among three sub-datasets (i.e., single-tip "full+glob", "thin" and "empty" for head and single-tip "thin" as well as for double-tip "thin+empty" for the acrosome morphology) of the two subspecies differed most significantly. However, no significant difference was established between the acrosome morphological data of single-tip “push" among M. hartingi males (Tab. 7, Fig. 1).

According to Parametric $p$ value, Permutation $p$ value and $p$ value of the Procrustes distance, DFA confirmed statistically significant difference in shape between subdatasets of single-tip "full+glob", "thin" and "empty" for head morphology and among sub-datasets single-tip "thin" for acrosome morphology between $M$. h. hartingi and M. h. lydius (Tab. 8).

In CVA, most significant shape changes of the positive and negative directional deformation according to CV1 were expressed in slimmer general shape as well as more protruded (stretched outwards) basal part of the head for single-tip "full+glob" (Fig. 4A) and "empty" (Fig. 4B, see on right). M. h. lydius sub-datasets of the head morphology showed more compressed and flattened shape and the tip pointed towards the ventral side compared to the $M$. h. hartingi. As for the acrosome morphology, Single-tip "thin" sub-datasets of $M$. h. lydius acrosomes in comparison to $M$. h. hartingi, had narrower and pointed more apically, not ventrally acrosomes (Fig. 4C). Nevertheless, the morphology of acrosome of the sub-datasets with double-tip "thin+empty", the CVA separated the general shape variation of narrower and more cone-shaped acrosome with its both tips pointing closer to each other for $M$. $h$. lydius compared to $M$. $h$. hartingi.

According to reclassification in DFA, the histogram analysis of the head morphology revealed that $M . h$. hartingi and $M$. h. lydius samples were discriminated strongly with six of nine misclassified units for singletip "full+glob" (Fig. 5A, left) and "thin" (Fig. 5B, left) sub-datasets respectively. Data samples of both vole subspecies were discriminated and statistically most significant among the single-tip "empty" sub-datasets (Fig. 5C, left). However, for the acrosome morphology, there was a lower discrimination with more than 30 out of 150 units misclassified in sub-datasets of the single-tip "thin"; regarding DFA histogram analysis of discriminant scores (Fig. 5D, left). In accordance with DFA of the general shape deformation, the shape of the head of $M$. h. hartingi statistically significantly differed from $M$. h. lydius. This manifests in more globular head shape with less stretched acrosome apically regarding

Table 7. Percentage of total variance (\% Var) of the data explained by first five PCs among two vole subspecies $M$. hartingi hartingi and $M$. h. lydius.

\begin{tabular}{|c|c|c|c|c|c|c|}
\hline \multirow{5}{*}{ 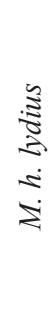 } & \multirow{2}{*}{ Groups } & \multicolumn{5}{|c|}{ M. h. hartingi (dataset applied accordingly) } \\
\hline & & Dataset & $\%$ Var PC1 & $\%$ Var PC2 & $\%$ Var $\mathrm{PC} 1+\mathrm{PC} 2$ & $\%$ Var PC1-PC5 \\
\hline & \multirow{2}{*}{ Head } & $\begin{array}{l}\text { Single-tip } \\
\text { «full+glob» }\end{array}$ & 40.516 & 17.606 & 58.122 & 85.227 \\
\hline & & $\begin{array}{l}\text { Single-tip } \\
\text { «empty» }\end{array}$ & 27.472 & 20.259 & 47.731 & 84.958 \\
\hline & Acrosome & $\begin{array}{l}\text { Single-tip } \\
\text { «thin» }\end{array}$ & 63.333 & 21.965 & 85.298 & 98.766 \\
\hline
\end{tabular}

Table 8. CVA results for datasets of acrosome and head geometric morphometrics (Mah. Dist.: Mahalanobis distance, Proc. Dist.: Procrustes distance, Perm. p: Permutation p value, Bolded: statistically significant difference). Statistically significant $p$-values $(\mathrm{p}<0.05)$ are in bold.

\begin{tabular}{|c|c|c|c|c|c|c|}
\hline \multirow{8}{*}{ 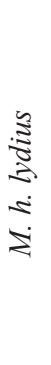 } & \multirow{2}{*}{ Groups } & \multicolumn{5}{|c|}{ M. h. hartingi (dataset applied accordingly) } \\
\hline & & Dataset & Mah. dist. & Perm. p. & Proc. dist. & Perm. $p$. \\
\hline & \multirow{4}{*}{ Head } & Single-tip «full+glob» & 3.0506 & $<0.0001$ & 0.0414 & $<0.0001$ \\
\hline & & Single-tip «thin» & 2.8514 & $<0.0001$ & 0.0518 & $<0.0001$ \\
\hline & & Single-tip «empty» & 7.2588 & $<0.0001$ & 0.0634 & $<0.0001$ \\
\hline & & Single-tip «push» & 4.9352 & 0.0002 & 0.0647 & 0.1514 \\
\hline & \multirow[b]{2}{*}{ Acrosome } & Single-tip «thin» & 2.4962 & $<0.0001$ & 0.144 & $<0.0001$ \\
\hline & & $\begin{array}{l}\text { Double-tip } \\
\text { «thin+empty» }\end{array}$ & 2.6048 & $<0.0001$ & 0.1225 & 0.0064 \\
\hline
\end{tabular}



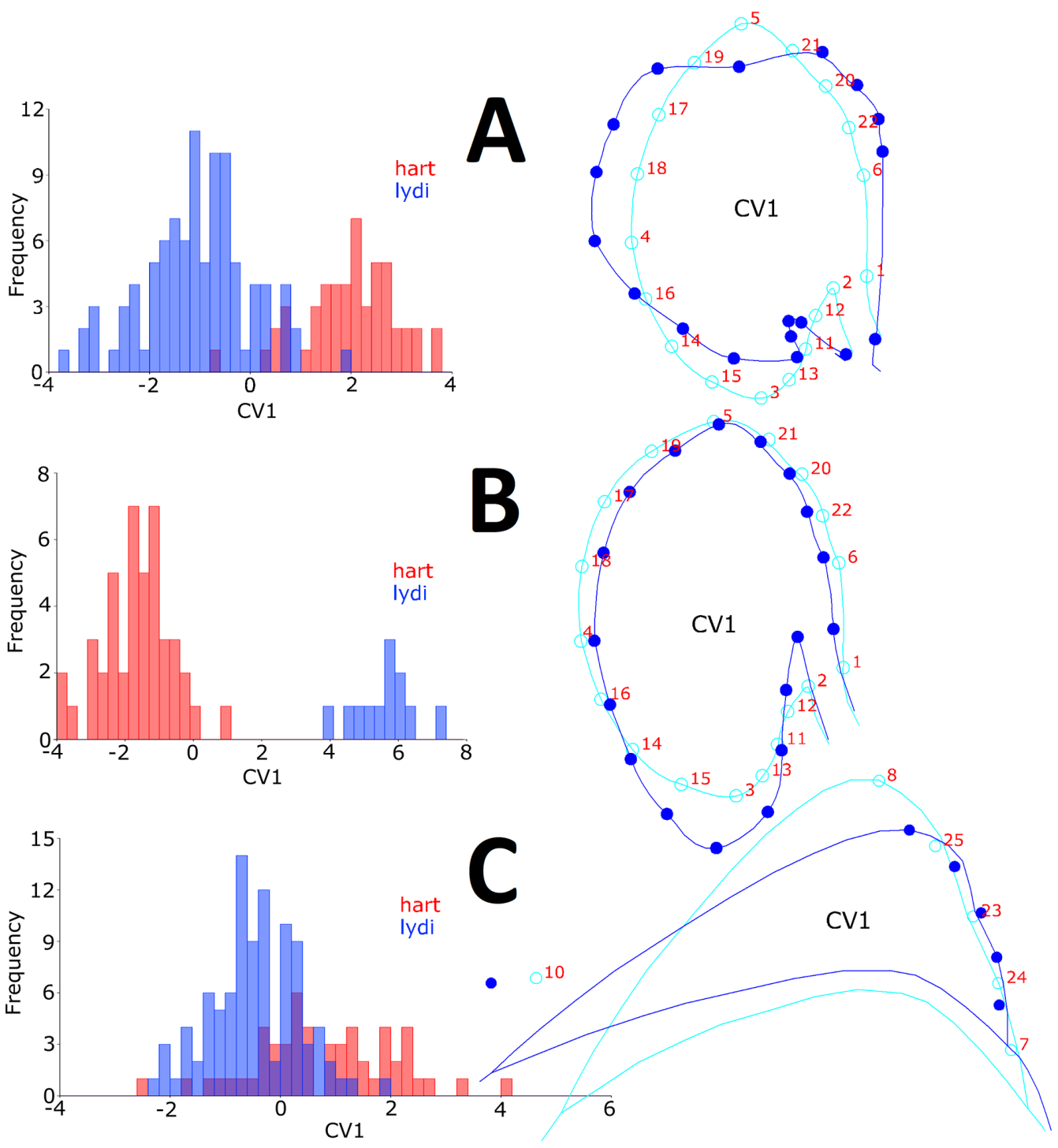

Fig. 4. CVA histogram scores of the head (A, B) and acrosome (C) morphology (on left), and general shape deformation (on right) among the two vole subspecies (hart: Microtus hartingi hartingi marked red, lydi: M. h. lydius marked blue) in accordance to Canonical variate 1 (curves of consensus shape marked light blue, curves of the positive directional shape changes coloured dark blue, consensus and deformation landmarks symbolised by empty and filled dots respectively and numbered in red, scale factor: 20.0 for A, B and 2.5 for C).

head morphological variability of single-tip "full+glob" sub-datasets (Fig. 5A, right) as well as in a less elongated and more retracted basal part of the spermatozoa head, regarding head morphological variability of single-tip "thin" sub-datasets (Fig. 5B, right). M. h. hartingi differed from $M . h$. lydius most strongly in the morphological variation of the head among the single-tip "empty" subdatasets by, similarly, having more retracted basal part of the spermatozoa head and more wide and globular overall shape (Fig. 5C, right). Regarding differences in acrosomes, $M$. h. hartingi had acrosomes dorsal-ventrally longer and apically more compressed among the single-tip "thin" sub-datasets, contrary to the spermatozoa of $M$. $h$. lydius subspecies having more pointed and apically stretched acrosomes (Fig. 5D, right).

\section{Discussion}

According to the analysis of linear morphometrics, both subspecies of the Harting's vole have large spermatozoa head sizes, which confirm the previously established consistent pattern. The largest spermatozoa are characteristic for species of the "guentheri" group (Zorenko \& Golenishchev, 2015). However, we observed significant differences in the length and width of the spermatozoon head of $M$. h. lydius males between two studies carried out (the present study and the study of Zorenko \& Golenishchev, 2015). We distinguish two reasons for these differences. The first is the different preparation of slides of spermatozoa. In the study of Zorenko \& Golenishchev (2015), the spermatozoa were 

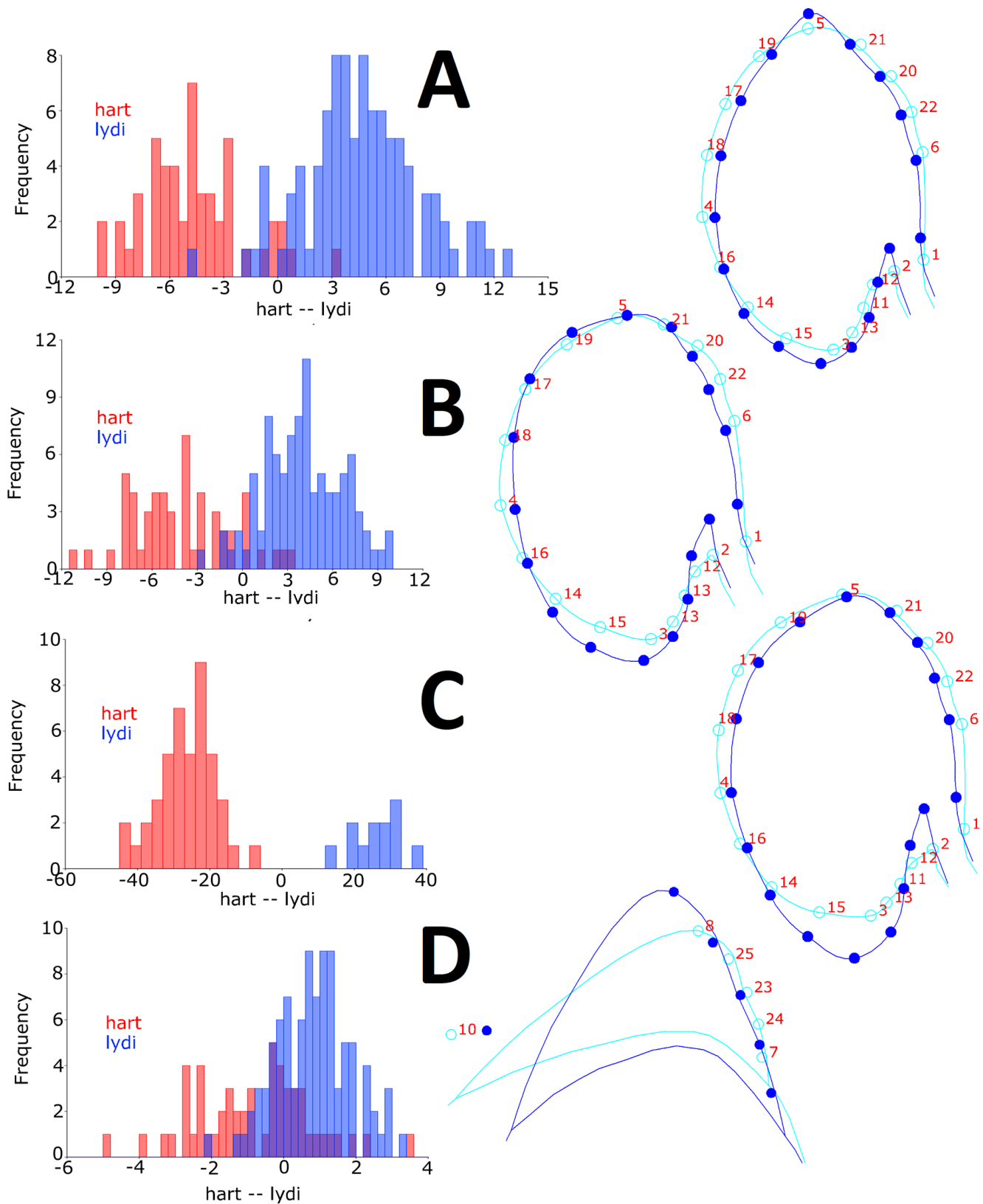

Fig. 5. DFA discriminant function histogram scores of the head (A, B, C) and acrosome (D) morphology on left, and general shape deformation on right among the two vole subspecies (hart: Microtus hartingi hartingi marked red, lydi: M. h. lydius marked blue) (curves of consensus shape marked light blue, curves of the shape deformation coloured dark blue, consensus and deformation landmarks symbolised by empty and filled dots respectively and numbered in red, scale factor: 2.5 ).

put onto slides in a drop of physiological solution. In present study, we fixed spermatozoa with formaldehyde in a phosphate buffer. The slides were painted identically by the methylene blue. The head size variability with the first method of fixation was smaller than with the second. The other reason is the differences in spermatozoa measurements: on freshly prepared slides (Zorenko \& Golenishchev, 2015) or based on photographed spermatozoa. According to our data, the length of spermatozoa in $M . h$. lydius is significantly larger than in $M$. h. hartingi (Tab. 3). However, a different result was obtained earlier: the head length in $M$. h. lydius is smaller than in $M$. $h$. strandzensis, inhabiting the southeastern part of the Balkans. Our results confirm the conclusion of other authors (Davis \& Gravance, 1994), that spermatozoa dimensions can vary significantly with different techniques and in different laboratories. It is necessary to unify the conditions for the first phase of 
the study, namely, the preparation of spermatozoa, then comparison of differences at species and subspecies level will be possible. However, the spermatozoa prepared in microscopic slides were also selected for making the images which were used for the shape analysis. We cannot exclude the possibility that a certain part of cells was fixed under the cover slide in a slightly angled position. This may result in an optical projection of the cell from which linear and shape properties measured show different values compared to the cells that were fixed in their total profile.

From the beginning of the morphological analyses, we visually registered grouping the shape of vole spermatozoa head into five types of that were showing also progression from one to another namely "full", "thin", "empty", "glob" and "push" (see Fig. 1). Thus, the positions and presence of main landmarks were determined not only by the general shape changes, but also by the type of the spermatozoa head. During the geometric morphometric analysis, the shape of the spermatozoa head of $M . h$. hartingi was characterized as more globular, with more retracted basal part compared to the slimmer $M$. $h$. lydius head shape with stronger developed basal protrusion. Similarly, slenderer pointytip acrosome shape of $M$. $h$. lydius spermatozoa was established, which differing from the heads of $M$. $h$. hartingi spermatozoa with apically more compressed to the head type acrosome (Figs 3-5). When shape data is compared with dimensions-derived parameters, it can be seen that the width of a spermatozoa head is smallest in M. h. lydius (Zorenko \& Golenishchev, 2015). However, this conclusion is not confirmed by other sperm fixation methods used in our study (Tab. 3). We reveal the variability of $M$. hartingi spermatozoa in the shape and location of the acrosome. According to the shape of the acrosome cap, two types are distinguished: 1) with the single-tip and 2) with the double-tip acrosome (Tab. 1, Fig. 2). We have also identified several types of acrosomes depending on their location and visibility. The acrosome fully fused together with the spermatozoon head (1) (see "full" in Fig. 2A). The acrosome separated from the spermatozoon head with the thin line (2) (see "thin" in Fig. 2B). However, these types are not different. Apparently, the light microscopy could not define the acrosome membranes and its boundaries (Fawcett, 1975). In some cases, we could better observe the border of the apical part of the acrosome; in others, it was not visible. The empty-like acrosome cap is "separated" from the spermatozoon head (3) (see "empty" in Fig. 2C). However, we can explain this "emptiness" by the fact, the acrosome content is not homogeneous. The equatorial segment of acrosome has distinct areas of differing density. Fawcett (1975) described similar observation in some rodent species. Finally, the acrosome not discernible from the spermatozoon head, the apex of the head round or protruding inward (4) (see "glob" and "push" in Fig. 2D, E), which indicates an unformed apical segment of the acrosome.

Spermatozoa with the double-tip acrosome are more common in $M$. h. hartingi and rare in $M . h$. lydius but apparently, cannot be considered as normal cells, their proportion is small in both taxa. We guess that roundshaped sperm heads with no discernible acrosome (at least those observed with a light microscope) are abnormal (types D and E, see Fig. 1 and Tab. 4). Escalier (1990) showed that a round-headed sperm head anomalies in human spermatogenesis result from a failure of differentiation of the spermatozoa-specific skeletal complex related to the nucleus. Perhaps in this case, the "glob", "push" and "double-tip" types of spermatozoa head are not the representations of a degenerative cells and their appearance might be reflecting the evolution of spermatozoa as a transition from a hooked shape to a simpler non-hooked spermatozoonon shape.

The two subspecies differed in dominance of spermatozoa type occurrence among the observed vole individuals. The dominant spermatozoa type in $M . h$. hartingi is single-tip "thin" (62\%) and a single-tip "full" (35\%). The opposite relationship of spermatozoa types is observed in $M$. h. lydius $-36 \%$ and $58 \%$ respectively (Tab. 4). The double-tip spermatozoa type occurs in $M . h$. hartingi 5.7 times more frequently than in $M$. $h$. lydius (Tab. 4). The head shape C, D and E ("empty", "glob" and "push") occur relatively rarely in both subspecies of $M$. hartingi (Tab. 4). Thus, only one type of spermatozoa head is characteristic of the M. hartingi males. All three variants (single-tip "thin", single-tip "full" and "empty") of the shape correspond to this type and account for more than $97 \%$. Which of polymorphic spermatozoa are normal or abnormal and how does spermatozoa morphology? Abnormalities associated with the sperm flagellum are widely represented in $M$. hartingi. We found several types of gins that form the tail, as well as tails completely separated from the head (Tab. 4). The gins of the tail are especially common in $M . h$. hartingi (61\%) but spermatozoa heads separated from the tails are more typical for $M$. h. lydius (58\%). The age of males may have increased an effect on the occurrence of abnormal spermatozoa head and tails; old males have more defect spermatozoa (Smirnov \& Davidova, 2018). The males chosen for our study were at the most reproductive age (4-6 months old) and had an offspring; therefore, we speculate that variations of the head shape cannot be a result of the age impact. The neck width does not differ between the two taxa but it is quite thin (Fig. 1). Therefore, at this place the decapitation of the sperm head from the flagellum is possible. Finely, we also doubt that changes in the structure of spermatozoa can be the result of laboratory preparation. We can assume that the decapitation of the sperm head is noted for both the methylene blue stained, and the unstained spermatozoa. However, in $M$. $h$. lydius, the head separation occurs more often during staining (see Tab. 5). At the same time, we did not notice an increase in the gins on the tail. It is impossible to exclude the impact of such a factor as mutations. It is shown that the "azh" (means) autosomal recessive mutation in the murine Hook1 gene causes tail abnormalities often resulting in coiled sperm tails or in the decapitation of the sperm head from the flagellum. The azh spermatozoa are sensitive to mechanical forces, 
which often cause tail detachment (Mendoza-Lujambio et al., 2002). This may be the reason for the increase in the number of sperm heads without flagella during staining of slides in $M$. h. lydius.

Inbreeding can also influence spermatozoa degeneration (Keller \& Waller, 2002). Our laboratory and field observations show inbreeding in natural population of $M$. h. hartingi from Rhodope Mountains. In addition, both vole subspecies successfully were breed several generations in laboratory conditions. Nevertheless, tail anomalies of spermatozoids are relatively common, but defects of acrosomes are rare.

Though there are found significant differences in the head shape and sizes of the acrosome of spermatozoa in the subgenera Microtus s. str. and Sumeriomys (Zorenko \& Golenishchev, 2015), they do not become an absolute barrier for hybridization of these taxa. Hybrids obtained by crossing the two species M. socialis Pallas, 1773 and M. rossiaemeridionalis Ognev, 1924, confirm this (Kovalskaya et al., 2014). Perhaps the double-tip spermatozoa could fertilize the oocyte during hybridization of these two species. Our results are interesting to test the possibility of hybridization between the species having different type of a spermatozoa shape and dimensions. Earlier it was shown that a hybrid offspring could be received only between species with similar spermatozoa design. In case when they are different, the interbreeding is usually without a positive result. Therefore, when Alexandromys mongolicus (Radde, 1861) and M. rossiaemeridionalis or $M$. arvalis (Pallas, 1778) were crossing, descendants could not be received (Meyer et al., 1996).

The variability of the shape of spermatozoa in social voles is not so great compared to this of naked mole-rat (Heterocephalus glaber Rüppell, 1842) (Horst van der et al., 2011). The authors observed that the spermatozoa structure is extremely polymorphic under the transmitted light microscopy. Moreover, most spermatozoa were classified as abnormal. Indeed, the shape of the spermatozoa head of a naked mole rat may be round, oval, elongated, lobed, asymmetrical and amorphous. More, the electron microscopy additionally showed that spermatozoa of this species are simplified and degenerated in many aspects (Sánchez et al., 2013). However, it must also be taken into consideration that during the preparation for SEM procedures deformation can occur (as the artefacts in a cell structure caused by drying or staining the spermatozoa sample) of not only surface microstructure but also the general spermatozoa shape (Nowell \& Pawley, 1980; Nussdorfer et al., 2018). Since spermatozoa studies have not been enough widely conducted in general, it is not possible to judge the overall process of simplification and degeneration of the spermatozoa in M. hartingi. However, the spermatozoa in all social voles have a simplified shape and structure compared to other rodent species, having the acrosome with a hook of different lengths.

The social voles (Sumeriomys) are the only subgenus in the tribe Microtini in which males have a simple spermatozoa form without a hook. All species of this subgenus both in "socialis" group and in "guentheri" group have an oval head and the acrosome covers the body of spermatozoid head apically. At the same time, the largest spermatozoa are characteristic for "guentheri" group species in comparison with "socialis" group (Zorenko \& Golenishchev, 2015). The geometric morphometric analysis shows differences between two subspecies concerning the head and the acrosome morphology.

Roldan et al. (1992) suggested that a rostral hooked spermatozoa head had evolved from a non-hooked, more primitive type in four separate lineages in the Cricetidae family (subfamilies Neotominae Merriam, 1894, Sigmodontinae Wagner, 1843, Cricetinae Fischer, 1817 and Arvicolinae Gray, 1821). However, another spermatozoa evolution scenario is possible: at the beginning of speciation, spermatozoa were received a rostral hook. Later a loss of hook and simplification of the shape of the spermatozoa head could happen (Aksenova, 1978; Breed, 2005; Horst van der et al., 2011). The subgenus Sumeriomys is the group of evolutionary young species (Gromov \& Polyakov, 1977). Therefore, the absence of a hook-shape acrosome is an evolutionary new acquisition in vole's speciation. The simplification of the acrosome shape is noted in different families and genera of rodents (Breed, 2005). Apparently, it is a parallelism, so common for different morphological structures. They have evolved independently in each of the separate lineages of animals.

In conclusion, we recommend the methods of the spermatozoa shape analysis to consider variations of this cell structure in mammals at species and subspecies levels. Linear morphometry of spermatozoa may be less successful due to the methodological features of preparing spermatozoa slides for subsequent analysis.

ACKNOWLEDGEMENTS. We would like to express our great gratitude to Dr. Fedor Golenishchev from the Zoological Institute Russian Academy of Sciences for providing the founders $M$. h. lydius for our laboratory colony. We also are thankful to Dr. Turs Selga from the University of Latvia, Faculty of Biology for advising on rodent sperm preparation and microscopy. We thank Dr. Nasko Atanasov from the Bulgarian Academy of Sciences for provided help and comments on English and to Dr. Andrei Miljutin of Tartu University for the constructive comments and fruitful discussions of previous versions of the manuscript.

\section{References}

Abramson N.I. \& Lissovsky A.A. 2012. Subfamily Arvicolinae // Pavlinov I.Ya. \& Lissovsky A.A. (eds.). The Mammals of Russia: A Taxonomic and Geographic Reference (Archive of the Zoological Museum of MSU. Vol.52). Moscow: KMK Scientific Press. P.220-276.

Aksenova T.G. 1978. [The peculiarities of spermatozoa structure and their significance in systematic of grey voles (Rodentia, Microtus)] // Strelkov P.P. (ed.). [Functional Morphology and Systematics of Mammals]. Leningrad: 
Russian Academy of Science. P.91-101 [in Russian with English summary].

Bookstein F.L. 1996. Standard formula for the uniform shape component in landmark data // Marcus L.F., Corti M., Loy A., Naylor G.J.P. \& Slice D.E. (eds.). Advances in Morphometrics. New York: Plenum Press. P.153-158.

Breed W.G. 2004. The spermatozoon of Eurasian murine rodents: its morphological diversity and evolution // Journal of Morphology. Vol.261. P.52-69.

Breed W.G. 2005. Evolution of the spermatozoon in muroid rodents // Journal of Morphology. Vol.265. P.271-290.

Çağatay M.N., Görür N., Algan O., Eastoe C., Tchapalyga A., Ongan D., Kuhn T. \& Kuşçu I. 2000. Late Glacial-Holocene paleoceanography of the Sea of Marmara: timing of connections with the Mediterranean and the Black seas // Marine Geology. Vol.167. P.191-206.

Cummins J.M. \& Woodall P.F. 1985. On mammalian sperm dimensions // Journal of Reproduction and Fertility. Vol.75. P.153-175.

Davis R.O. \& Gravance C.G. 1994. Consistency of sperm morphology classification methods // Journal of Andrology. Vol.15.No.1. P.83-91.

delBarco-Trillo J. \& Ferkin M.H. 2006. Male meadow voles respond differently to risk and intensity of sperm competition // Behavioral Ecology. Vol.17. P.581-585.

Directive 2010/63/EU of the European Parliament and of the Council of 22 September 2010 on the protection of animals used for scientific purposes // Official Journal of the European Communities. Vol.276. P.33-52.

Ellerman J.R. 1941. The Families and Genera of Living Rodents. Vol.2. London: British Museum (Natural History). $690 \mathrm{p}$.

Escalier D. 1990. Failure of differentiation of the nuclear-perinuclear skeletal complex in the round-headed human spermatozoa // International Journal of Developmental Biology. Vol.34. P.287-297.

Fawcett D.W. 1975. The mammalian spermatozoon // Developmental Biology. Vol.4. P.394-436.

Golenishchev F.N., Sablina O.V., Borodin P.M. \& Gerasimov S. 2002. Taxonomy of voles of the subgenus Sumeriomys Argyropulo, 1993 (Rodentia, Arvicolinae, Microtus) // Russian Journal of Theriology. Vol.1. No.1. P.43-55.

Gromov I.M. \& Polyakov I.Ya. 1992. Voles (Microtinae): Fauna of the USSR, Mammals. Vol.3. No.8. Washington: Smithsonian Institution Libraries and the National Science Foundation. 725 p.

Guillén J. 2017. Laboratory animals: regulations and recommendations for the care and use of animals in research. Second edition. London: Academic Press. 444 p.

Horst van der G., Maree L., Kotzé S.H. \& O'Riain M.J. 2011. Sperm structure and motility in the eusocial naked mole-rat, Heterocephalus glaber: a case of degenerative orthogenesis in the absence of sperm competition? // BMC Evolutionary Biology. Vol.11. P.1-11.

Ieradi L.A., Zima J., Allegra F., Kotlánová E., Campanella L., Grossi R. \& Cristaldi M. 2003. Evaluation of genotoxic damage in wild rodents from a polluted area in the Czech Republic // Folia Zoologica. Vol.52. No.1. P.57-66.

Jeong S.J., Park J.C., Kim H.J., Bae C.S., Yoon M.H., Lim D.S. \& Jeong M.J. 2006. Comparative fine structure of the epididymal spermatozoa from three Korean shrews with considerations on their phylogenetic relationships // Biocell. Vol.30. No.2. P.279-286.

Keller L.F. \& Waller D.M. 2002. Inbreeding effects in wild populations // Trends in Ecology and Evolution. Vol.17. P.230-241.

Klingenberg C.P. 2011. MorphoJ: an integrated software package for geometric morphometrics // Molecular Ecology Resources. Vol.11. P.353-357.

Kovalskaya Yu.M., Savinetskaya L.E. \& Aksenova T.G., 2014. On experimental interspecific hybridization of voles of the genus Microtus: M. socialis with species of the arvalis group (Mammalia, Rodentia) // Bulletin of the Russian Academy of Sciences. Biological Series. No.6. P.636-640.

Kryštufek B., Vohrálik V., Zareie R. \& Özkan B. 2009. Mitochondrial cytochrome $b$ sequences into the speciation of social voles in southwest Asia// Biological Journal of the Linnean Society. Vol.98. No.1. P.121-128.

Krzanowska H., Styrna J. \& Wabik-Śliz B. 1995. Analysis of sperm quality in recombinant inbred mouse strains: correlation of sperm head shape with sperm abnormalities and with the incidence of supplementary spermatozoa in the perivitelline space // Journal of Reproduction and Fertility. Vol.104. P.347-354.

Latvian Council of Science 2018. Scientist's Ethics Code. Section 2.7. Riga. Available at https://www.lzp.gov.lv/ index.php?mylang=english.

Medarde N., Muños-Muñoz F., López-Fuster M.J. \& Ventura J. 2013. Variational modularity at the cell level: insights from the sperm head of the house mouse // BMC Evolutionary Biology. Vol.13. P.179-185.

Mendoza-Lujambio I., Burfeind P., Dixkens C., Meinhardt A., Hoyer-Fender S., Engel W. \& Neesen J. 2002. The Hook1 gene is non-functional in the abnormal spermatozoon head shape (azh) mutant mouse // Human Molecular Genetics. Vol.11. P.1647-1658.

Meyer M.N., Golenishchev F.N., Radjably S.I. \& Sablina O.V. 1996. Grey Voles (Subgenus Microtus Schrank) of Russia and Adjacent Territories. Saint Petersburg: Russian Academy of Science. 320 p. [in Russian with English summary].

Michalczyk Ł., Martin O.Y., Millard A.L., Emerson B.C. \& Gage M.J.G. 2010. Inbreeding depresses sperm competitiveness, but not fertilization or mating success in male Tribolium castaneum // Proceedings of the Royal Society B, Biological Sciences. Vol.277. P.3483-3491.

Miska-Schramm A., Kapusta J. \& Kruczek M. 2017. The effect of aluminum exposure on reproductive ability in the bank vole (Myodes glareolus) // Biological Trace Element Research. Vol.177. No.1. P.97-106.

Moore A.J., Bacigalupe L.D. \& Snook R.R. 2013. Integrated and independent evolution of heteromorphic sperm types // Proceeding of the Royal Society B, Biological Sciences. Vol.280. P.1-5.

Musser G.G. \& Carleton M.D. 2005. Superfamily Muroidea // Wilson D.E. \& Reeder A.M. (eds.). Mammal Species of the World. A Taxonomic and Geographic Reference. Third edition. Vol.2. Baltimore: The Johns Hopkins University Press. P.894-1531.

Nowell J.A. \& Pawley J.B. 1980. Preparation of experimental animal tissue for SEM // Murphy J.A. \& Romans G.M. (eds.). Preparation of Biological Specimens for Scanning 
Electron Microscopy. O'Hare: Scanning Electron Microscopy. P.1-19.

Nussdorfer P., Cilenček I., Zorn B. \& Petrovič D. 2018. Adapted methods for scanning electron microscopy (SEM) in assessment of human sperm morphology // Bosnian Journal Basic Medical Sciences. Vol.18. No.1. P.43-48.

Pitnick S., Hosken D.J. \& Birkhead T.R. 2009. Sperm morphological diversity // Birkhead T.R., Hosken D.J. \& Pitnick S. (eds.). Sperm Biology: an Evolutionary Approach. San Diego: Academic Press. P.69-149.

R Development Core Team. 2019. R: A language and environment for statistical computing. Vienna: $\mathrm{R}$ Foundation for Statistical Computing. Retrieved from https://www.r-project.org.

Ramm S.A. \& Stockley P. 2007. Ejaculate allocation under varying sperm competition risk in the house mouse, Mus musculus domesticus // Behavioral Ecology. Vol.18. No.2. P.491-495.

Rohlf F.J. 2016. Morphometrics. Suny Stony Brook. Available at https://life.bio.sunysb.edu/morph/index.html.

Rohlf F.J. \& Slice D.E. 1990. Extensions of the Procrustes method for the optimal superimposition of landmarks // Systematic Zoology. Vol.39. P.40-59.

Roldan E.R.S., Gomendio M. \& Vitullo A.D. 1992. The evolution of eutherian spermatozoa and underlying selective forces: female selection and sperm competition // Biological Reviews. Vol.67. P.551-593.

Roldan E.R.S., Cassinello J., Abaigar T. \& Gomendio M. 1998. Inbreeding, fluctuating asymmetry, and ejaculate quality in an endangered ungulate // Proceedings of the Royal Society B, Biological Sciences. Vol.265. P.243-248.

Sánchez M.V., Bastir M. \& Roldan E.R.S. 2013. Geometric morphometrics of rodent sperm head shape // PLoS ONE. Vol.8. No.11. P.e80607.

Smirnov G.Ju. \& Davidova Ju.A. 2018. Effect of industrial pollution of the environment on the frequency of abnormal spermatozoa in the bank vole, Myodes glareolus // Russian Journal of Ecology. Vol.5. P.403-408.

Terrell K.A., Crosier A.E., Wildt D.E., O'Brien S.J., Anthony N.M., Marker L. \& Johnson W.E. 2016. Continued decline in genetic diversity among wild cheetahs (Acinonyx jubatus) without further loss of semen quality // Biological Conservation. Vol.200. P.192-199.

Tourmente M., Gomendio M. \& Roldan E.R.S. 2011. Sperm competition and the evolution of sperm design in mammals // BMC Evolutionary Biology. Vol.11. No.1. P.1-10. https://www.biomedcentral.com/1471-2148/11/12

Ward M.A. \& Burgoyne P.S. 2006. The effects of deletions of the mouse $\mathrm{Y}$ chromosome long arm on sperm functionintracytoplasmic sperm injection (ICSI)-based analysis // Biology of Reproduction. Vol.74. P.652-658.

Wyrobek A.J. \& Bruce W.R. 1975. Chemical induction of sperm abnormalities in mice // Proceedings of the National Academy of Sciences of USA. Vol.72. P.4425-4429.

Yaltırak C., Sakinç M. \& Oktay F.Y. 2000. Westward propagation of North Anatolian fault into the northern Aegean: timing and kinematics // Geology. Vol.27. P.187-188.

Yiğit N. \& Çolak E. 2002. On the distribution and taxonomic status of Microtus guentheri Danford and Alston, 1880 and Microtus lydius Blackler, 1916 (Mammalia: Rodentia) in Turkey // Turkish Journal of Zoology. Vol.26. P.197-204.

Yiğit N., Markov G., Çolak E., Kocheva M., Saygılı F., Yüce D. \& Çam P. 2012. Phenotypic features of the 'guentheri' group vole (Mammalia: Rodentia) in Turkey and Southeast Bulgaria: evidence for its taxonomic detachment // Acta Zoologica Bulgarica. Vol.64. No.1. P.23-32.

Zorenko T. \& Golenishchev G. 2015. The spermatozoa structure peculiarities of the subgenus Sumeriomys (Rodentia, Arvicolinae, Microtus) // Russian Journal of Theriology. Vol.14. No.1. P.105-111. 